Lydia Mechtenberg

Johannes Münster

\title{
A strategic mediator who is biased into the same direction as the expert can improve information transmission
}

Discussion Paper SP II 2010-19

December 2010

Social Science Research Center Berlin (WZB)

Research Area:

Markets and Politics

Research Unit:

Market Behavior

http://www.wzb.eu/mp/vam

E-mail: mechtenberg@wzb.eu 
( ) The copyright remains with the authors

Lydia Mechtenberg* and Johannes Münster†

A strategic mediator who is biased into the same direction as the expert can improve information transmission

Discussion Paper SP II 2010-19

Wissenschaftszentrum Berlin für Sozialforschung (2010)

*WZB, Reichpietschufer 50, 10785 Berlin, Germany. E-mail: mechtenberg@wzb.eu tFree University of Berlin, Boltzmannstraße 20, 14195 Berlin, Germany. E-mail:

johannes.muenster@fu-berlin.de

Social Science Research Center Berlin (WZB)

Research Area:

Markets and Politics

Research Unit:

Market Behavior
Wissenschaftszentrum Berlin für Sozialforschung gGmbH (WZB)

Forschungsschwerpunkt:

Märkte und Politik

Abteilung:

Verhalten auf Märkten

Reichpietschufer 50, D-10785 Berlin

Telefon: +49 30 25491-0, Fax: +49 30 25491-440

http://www.wzb.eu 


\section{Abstract}

This note reconsiders communication between an informed expert and an uninformed decision maker with a strategic mediator in a discrete Crawford and Sobel (1982) setting. We show that a strategic mediator may improve communication even when he is biased into the same direction as the expert. The mediator improves communication, however, only if some information transmission is possible with unmediated communication.

JEL classifications: C72, D82, D83

Keywords: Communication, Information, Cheap talk, Mediation

\section{Zusammenfassung}

In dieser Note wird die Kommunikation zwischen einem informierten Experten, einem strategischen Mediator und einem uninformierten Prinzipal in einer diskreten Umgebung à la Crawford und Sobel (1982) untersucht. Wir zeigen, dass ein strategischer Mediator die Kommunikation sogar dann verbessern kann, wenn sein Bias und der Bias des Experten gleichgerichtet sind. Diese Verbesserung der Kommunikation setzt jedoch voraus, dass bereits die Kommunikation ohne Mediator Informationstransmission ermöglicht. 


\section{Introduction}

Recent research has shown that a strategic mediator can improve upon communication in a Crawford Sobel (1982) setting, if his and the expert's bias point into opposite directions. Ivanov (2010) demonstrates that communication between a positively biased expert and the decision maker can be improved by a strategic mediator with negative bias. In fact, a strategic mediator with a specific negative bias can achieve as much information transmission in equilibrium as the optimal non-strategic mediator characterized by Goltsman et al. (2009). Ivanov (2010) also shows that, when the mediator is either unbiased or biased into the same direction as the expert, but to a lesser degree, the mediator cannot improve upon direct communication. ${ }^{1}$ This leaves open the question, however, whether a mediator with a stronger bias in the same direction as the expert may improve communication.

We show that, even when the biases point into the same direction, a strategic mediator can improve communication. We give an example that is kept as simple as possible to make this point. The mediator's bias is his private information and may either be zero (so that the mediator is unbiased) or greater than the bias of the expert. This introduces an uncertainty on the decision makers side about the expert's message, even when all players play pure strategies. ${ }^{2}$ As shown by Ambrus, Azevedo, and Kamada (2010), some uncertainty about the expert's message is needed to improve information transmission. Whereas in Ivanov (2010) and in Ambrus, Azevedo, and Kamada (2010) the uncertainty arises from a mixed equilibrium strategy of the mediator, in our setup it arises from the decision maker's uncertainty about the mediator's type. This allows us to focus on pure strategies and simplifies the equilibrium analysis. We find that the mediator can improve communication, but interestingly only if some information transmission is possible under direct communication. ${ }^{3}$

\footnotetext{
${ }^{1}$ Closely related are two recent papers. Ambrus, Azevedo, and Kamada (2010) consider a chain of strategic mediators, and give a sufficient condition for when a mediator improves communication in a fairly general setup. Ambrus, Azevedo, Kamada, and Katagi (2010) consider the open versus the closed rule in congressional decision making. They argue that, if communication between a legislature and a biased lobbyist is mediated by a committee, and the open rule is used, then the legislature will prefer a committee with a bias opposite to the lobbyist's.

${ }^{2} \mathrm{Li}$ and Madarasz (2007) show that not revealing the mediator's type can increase information transmission in mediated communication.

${ }^{3}$ The sufficient condition for when a mediator improves communication given by Am-
} 


\section{Model}

Nature chooses the state of the world $\theta$ from the uniform distribution over the set $\{0,1,2,3\} .{ }^{4}$ The expert learns $\theta$ and sends a message $s \in\{0,1,2,3\}$ to the mediator. The mediator learns $s$ (but not $\theta$ ) and sends a message $m \in\{0,1,2,3\}$ to the decision maker. Finally, the decision maker observes $m$ (but neither $s$ nor $\theta$ ) and chooses an action $a \in \mathbb{R}$. The payoffs of the expert, mediator, and decision maker are, respectively,

$$
\begin{aligned}
& u_{E}=-(a-(\theta+b))^{2}, \\
& u_{M}=-\left(a-\left(\theta+b_{M}\right)\right)^{2}, \\
& u_{D}=-(a-\theta)^{2} .
\end{aligned}
$$

The bias of the expert $b$ is strictly positive and commonly known. The bias of the mediator $b_{M}$ is his private information and takes value $b_{M}=0$ with probability $p \in(0,1)$ and $b_{M}=\beta>0$ with probability $1-p$. Note that the biases of the expert and the mediator point into the same direction. Without loss of generality, we focus on equilibria where different messages of the expert which are sent with positive probability in equilibrium lead to different probability distributions over actions. ${ }^{5}$

\subsection{Unmediated communication}

As a benchmark, consider the case of unmediated communication between the decision maker and the expert. For this case, it is straightforward to show the following: If $b<1 / 2$, a fully revealing equilibrium exists. If $1 / 2<b<1$, the optimal (i.e., most informative) equilibrium is a 2 -action equilibrium where type $\theta=0$ reveals his type truthfully, thereby separating himself from all the other types, and the other types pool on some other message. If $b>1$, only a babbling equilibrium exists and no information is transmitted. ${ }^{6}$

brus, Azevedo, and Kamada (2010) applies to settings where, whithout a mediator, there is only a babbling equilibrium and no information is transmitted. Our results thus point out that a mediator may improve communication under wider circumstances.

${ }^{4}$ For simplicity, we consider a discrete environment. The logic of our argument, however, does not depend on this. It will become clear below that we need at least four different states of the world to make our point.

${ }^{5}$ For any equilibrium where different messages of the expert lead to the same probability distribution over actions there exists an outcome equivalent equilibrium where these messages are replaced by one and the same message.

${ }^{6}$ See Appendix A.1 for a proof of these statements. 


\subsection{Mediated communication}

Ivanov (2010) shows that a strategic mediator whose bias points into the opposite direction as the expert's bias can ensure as much information transmission as an optimally chosen unstrategic mediator even if the expert's bias is so large that, in direct communication, only the babbling equilibrium would exist. In our setting, however, in which the mediator's and the expert's biases point into the same direction, introducing the mediator cannot improve upon the babbling equilibrium. This is especially interesting since, as we will show below, the mediator in our setting can improve upon equilibria in which there is some information transmitted in direct communication.

Proposition 1 If no information can be transmitted by direct communication between the decision maker and the expert, then no information can be transmitted by mediated communication either.

The intuition behind this result is the following. ${ }^{7}$ Suppose that some information can be transmitted with mediated communication. Then there exists an equilibrium of the mediated communication game where the expert of type $\theta=0$ separates himself, while the higher types $\theta=1,2,3$ pool. In this equilibrium, the mediator will send only two messages with positive probability. Similarly the decision maker takes only two different actions with positive probability. Hence we call the equilibrium a 2-action equilibrium. (See Figure 1 for an illustration of this and the subsequent argument.)

In order to improve communication if direct talk amounts only to babbling (i.e. if $b>1$ ), the mediator has to make sure that the lowest type prefers revealing his type over pooling with the others. Thus, the mediator must reduce the lowest type's incentive to exaggerate $\theta$.

Consider the 2-action equilibrium. After receiving the message that reveals type $\theta=0$, the mediator will either pass on this information, inducing a low action of zero (if he is unbiased), or else will distort the message upwards, inducing a higher action (if he is biased). Thus, if the expert of the lowest type reports truthfully to the mediator, he thereby chooses a lottery combined of the low and the high action. If, instead, he exaggerates his type, he gets the high action with certainty. Thus, he reveals his type to the mediator only if he prefers the low action over the high action.

\footnotetext{
${ }^{7}$ See Appendix A.2 for a proof based on this intuition.
} 
Note that the low action is exactly the same as the one that the decision maker would choose in an equilibrium of the direct communication game in which the lowest type of the expert is revealed - namely zero. The high action, however, is lower than the one that the decision maker would choose in a 2-action equilibrium of the direct communication game. This is due to the fact that in the 2-action equilibrium of the mediated communication game, the high message is less credible than in the 2-action equilibrium of the direct communication game. This, in its turn, is because in the mediated communication game, the high message could come from a biased mediator who exaggerates the type of the expert when in $\operatorname{truth} \theta=0$.

Given the concavity of the expert's preferences, the above considerations imply that if a 2-action equilibrium of the mediated communication game exists, then there is also a 2-action equilibrium of the direct communication game. Thus, the mediator cannot improve communication whenever $b>1$ so that direct talk amounts only to babbling.

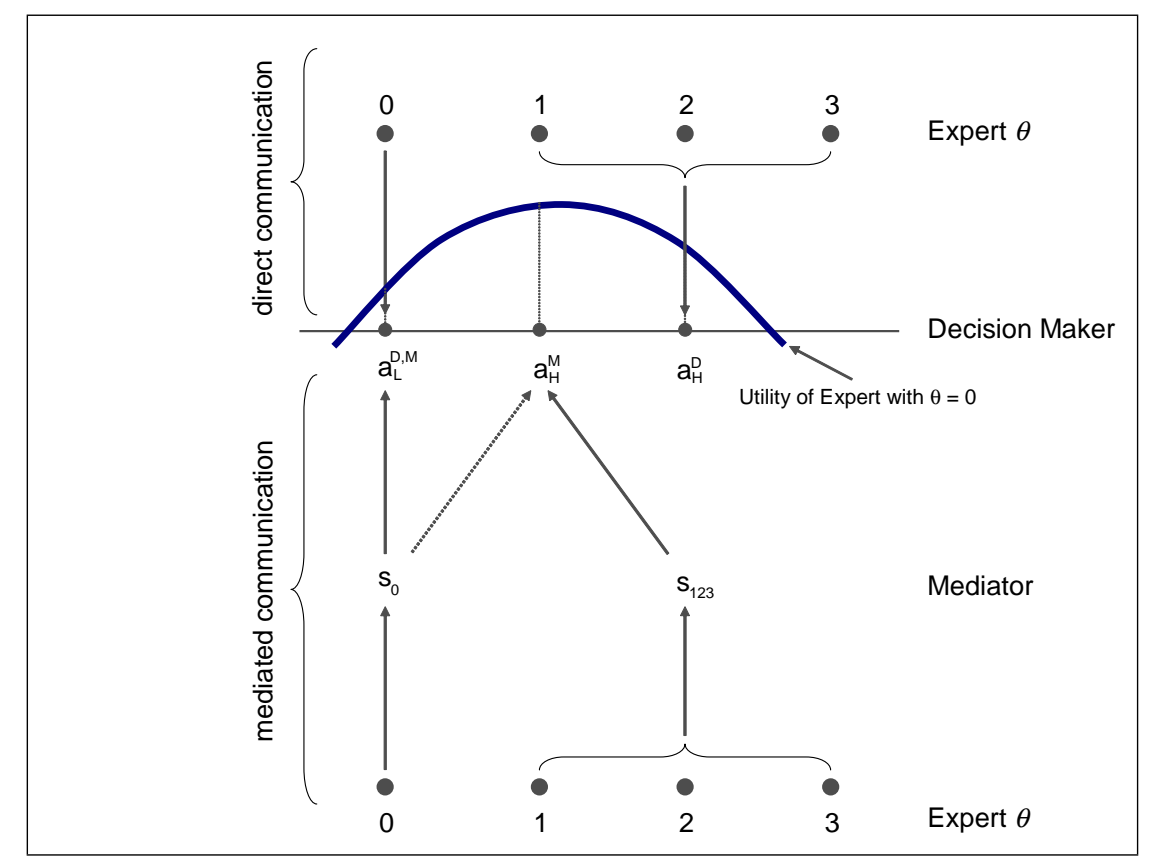

Figure 1: Direct communication versus mediated communication 
However, when there exists an equilibrium of the direct communication game in which at least some information is transmitted, having the mediator may improve communication:

Proposition 2 Suppose that $1 / 2<b<\bar{b} \approx 0.656$. Then there exists a positive measure set of parameters $(\beta, p)$ with $\beta>b$ and $p \in(0,1)$ such that mediation improves information transmission, compared to direct communication.

Note that for $1 / 2<b<\bar{b}$, where $\bar{b} \gtrsim 0.65$, the 2 -action equilibrium of the direct communication game exists and is the most informative equilibrium. To prove that strategic mediation can improve information transmission, we show that there exists a 3 -action equilibrium of the mediated communication game.

The equilibrium strategies are as follows (see Figure 2): Type $\theta=0$ of the expert sends a message $s_{0}, \theta=1$ sends a different message $s_{1}$, and 2 and 3 pool on a third message $s_{23}$. The unbiased type of the mediator truthfully reports what he has received. The biased mediator distorts communication upwards: after seeing $s_{0}$, he reports $s_{1}$, and after seeing $s_{1}$ or $s_{23}$, he reports $s_{23}$.

Given these strategies, the decision maker infers from $s_{0}$ that $\theta=0$ and thus chooses action $a_{1}=0$. After receiving $s_{1}$, the decision maker believes that $\theta=0$ with probability $1-p$ and $\theta=1$ with probability $p$, so he chooses $a_{2}=p$. After observing $s_{23}$, the decision maker believes that $\theta=1$ with probability $(1-p) /(3-p)$, and that $\theta=2$ and $\theta=3$ with probability $1 /(3-p)$ each. His choice of action in this case is $a_{3}=(6-p) /(3-p)$.

It is straightforward to show that for any $b \in\left(\frac{1}{2}, \bar{b}\right)$, these strategies are an equilibrium for a set of parameters $(\beta, p)$ with positive measure. ${ }^{8}$ (One example is $p=\beta=0.9$ and $b=0.6$.) The expected payoff of the decision maker in this equilibrium is

$$
\begin{aligned}
& -\frac{1}{4}\left(2(1-p) p^{2}+(1-p)\left(\frac{6-p}{3-p}-1\right)^{2}+\left(\frac{6-p}{3-p}-2\right)^{2}+\left(\frac{6-p}{3-p}-3\right)^{2}\right) \\
\geq & -\frac{1}{2}
\end{aligned}
$$

\footnotetext{
${ }^{8}$ See Appendix A.3.
} 


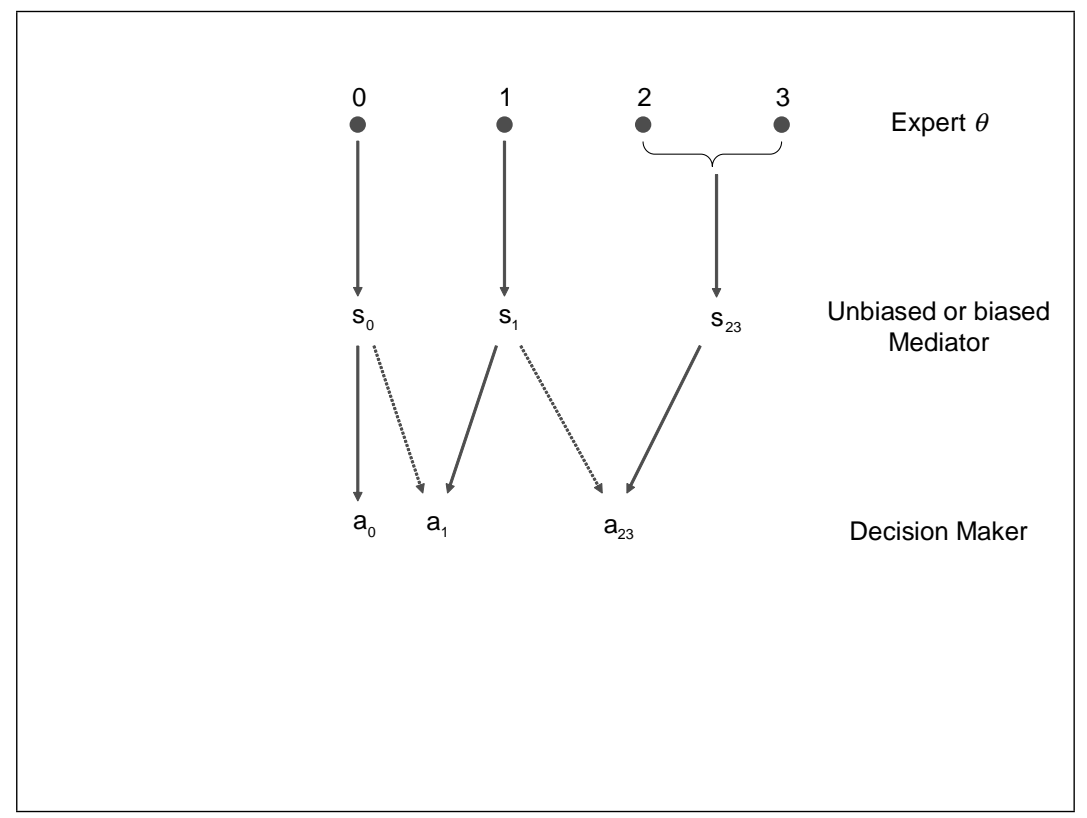

Figure 2: Best equilibrium of the mediated communication game

Thus, the decision maker gets a higher payoff in this equilibrium than in the 2-action equilibrium of the direct communication game, in which his payoff amounts to

$$
-\frac{1}{4}\left(0+(1-2)^{2}+0+(3-2)^{2}\right)=-\frac{1}{2} .
$$

We conclude that a strategic mediator with a positive bias - a bias pointing into the same direction as the expert's - can improve information transmission, but only if some information can already be transmitted via direct communication between the expert and the decision maker. The reason for this is the following: In order to give the lowest type of the expert an incentive to report honestly, the mediator has to make it more attractive for this type to reveal himself to the mediator (revelation) than to mimic the next-highest type (deviation). To achieve this, the mediator must make sure that (1) he moves to the right the action that the expert of type 0 expects in response to a revelation, and (2) that the decision maker's expected reactions to the revelation and to the deviation, respectively, are not two linear combinations of the same actions. Instead, the lottery of actions that the expert of type $\theta=0$ triggers by deviation must include some action $a^{\prime}$ that is higher than 
any possible action that the decision maker would choose after a revelation. If $a^{\prime}$ is sufficiently high, this guarantees that mimicking the next-highest type becomes less attractive to the expert with $\theta=0$ than revealing his true type.

Thus, the biased mediator has to distort both messages upwards: the one that reveals the lowest type of the expert and the next highest one. This, however, can only be done if there are at least three different messages sent by the expert in equilibrium, i.e. only if the mediated communication game has an equilibrium with at least three actions.

If the expert has a bias $b>1$, however, this is not possible. Thus, a strategic mediator with a positive bias can improve information transmission if the starting-point is a 2-action equilibrium of the direct communication game; but he cannot improve things if the starting point is a situation in which only the babbling equilibrium exists under direct communication.

\section{Conclusion}

Although our setting is extremely simple, it provides two important insights. The first insight is that a strategic mediator with a positive bias can improve communication - although for this to hold, at least some information transmission must already be possible via direct communication. The second insight concerns the relative intensities of the conflicts between the decision maker, the strategic mediator, and the expert: For the mediator to improve information transmission in Ivanov (2010), the conflict between the mediator and the expert must be more intensive than the conflict between the expert and the decision maker. In our setting, by contrast, the conflict between the mediator and the expert must be less intensive than the conflict between the mediator and the decision maker. This suggests that for any strategic mediator to improve communication, this mediator must be somewhat more extreme than the two parties whose conflict he is to alleviate: Either he must be more extreme than the decision maker (as in Ivanov (2010)), or he must be more extreme than the expert (as in our setting). We leave it to future research to explore this in a more general setting. 


\section{A Appendix}

\section{A.1 Unmediated communication}

We start by showing two standard properties in our context.

Lemma 1 Suppose that types $\theta$ and $\theta^{\prime}>\theta$ send the same message $s$. Then any $\theta^{\prime \prime}$ with $\theta<\theta^{\prime \prime}<\theta^{\prime}$ also send s.

Proof. Suppose to the contrary that $\theta^{\prime \prime}$ sends a message $s^{\prime \prime} \neq s$. Denote the action take by the decision maker after observing $s$ by $a$, and the action taken after observing $s^{\prime \prime}$ by $a^{\prime \prime}$. Suppose that $a<\theta^{\prime \prime}+b$. Then $a^{\prime \prime}>a$ since type $\theta^{\prime \prime}$ prefers $a^{\prime \prime}$. Moreover, $a^{\prime \prime}$ cannot be too far to the right of $\theta^{\prime \prime}+b$. But then $\theta^{\prime}$ prefers $a^{\prime \prime}$ over $a$, a contradiction. The remaining cases can be ruled out similarly.

Lemma 1 implies that, in any equilibrium, the set of expert's types is partitioned into cells, and types in the same cell send the same message. We call the difference between the highest and the lowest type belonging to the same cell the length of the cell.

Lemma 2 In the most informative equilibrium, the length of the cells of the partition is weakly increasing.

Proof. To prove this, it is sufficient to rule out the following three possibilities. (i) Types 0 and 1 pool, while types 2 and 3 send separate messages. Then we must have $b \leq 1 / 2$, for otherwise 2 would have an incentive to imitate 3 . But then a fully separating equilibrium exists. (ii) Types 1 and 2 pool, while types 0 and 3 send separate messages each. Then $b \leq 1 / 4$, otherwise 2 prefers to imitate 3 , and again a fully separating equilibrium exists. (iii) Types 0,1 , and 2 pool while type 3 separates himself. This cannot be an equilibrium since for any $b>0$, type 2 prefers to imitate type 3 .

We are now in a position to consider the most informative equilibrium. It is straightforward that, whenever $b<1 / 2$, there is a fully revealing equilibrium. If $1 / 2<b<1$, there is no equilibrium where types 0 and 1 send separate messages which fully reveal their respective types, since then type 0 would prefer to imitate type 1 . In particular, there is no fully separating equilibrium. Moreover, there is no equilibrium where 0 and 1 pool on some message $s$ while 2 and 3 pool on a different message $s^{\prime} \neq s$, since type 1 would prefer to send $s^{\prime}$. However, there is an equilibrium where type 0 separates 
himself and types 1, 2, and 3 pool. By Lemma 2, it follows that this is the most informative equilibrium. Finally, if $b>1$, this equilibrium breaks down since type 0 would prefer to imitate the others. Hence there is no information transmission in equilibrium.

\section{A.2 Mediation does not improve communication if $b>$ 1}

Call an equilibrium a n-action equilibrium if the decision makers takes $\mathrm{n}$ different actions with positive probability on the equilibrium path. The following lemma is the key step in our argument.

Lemma 3 Suppose that without mediation there is no 2-action equilibrium. Then with mediation there is no 2-action equilibrium either.

Proof. Suppose that with mediation there is a 2-action equilibrium. There is a critical type $\theta^{\prime}$ such that in the supposed equilibrium, all $\theta \leq \theta^{\prime}$ send the same "low" message, and all $\theta>\theta^{\prime}$ send the same "high" message. (This can be shown by essentially the same argument as in the proof of Lemma 1 , replacing actions by certainty equivalents of the lotteries over actions induced by messages of the expert.) Furthermore, the mediator cannot report truthfully always because then a 2-action equilibrium would exist without mediation as well. The unbiased mediator never has an incentive to distort the message. The biased mediator will distort the message, if at all, only upwards. Thus, in the supposed equilibrium the mediator reports truthfully if he is unbiased, and always sends the high message when he is biased.

When the decision maker receives the low message from the mediator, he knows that $\theta \leq \theta^{\prime}$ and chooses his action equal to the average of these types, i.e.

$$
a_{l}=\frac{1}{\theta^{\prime}+1} \sum_{\theta=0}^{\theta^{\prime}} \theta .
$$

When the decision maker receives the high message from the mediator, he chooses some action $a_{h}$ which is strictly in between $a_{l}$ and the average of the types of the expert that send the high message:

$$
a_{l}<a_{h}<\frac{1}{4-\theta^{\prime}} \sum_{\theta=\theta^{\prime}+1}^{4} \theta
$$


Consider the critical type $\theta^{\prime}$ in this equilibrium. By assumption, without mediation there is no 2-action equilibrium where types $\theta \leq \theta^{\prime}$ send a low message and all others a high message. This implies that type $\theta^{\prime}$ strictly prefers $\frac{1}{4-\theta^{\prime}} \sum_{\theta=\theta^{\prime}+1}^{4} \theta$ over $a_{l}$. By concavity of the payoff functions, $\theta^{\prime}$ strictly prefers $a_{h}$ over $a_{l}$. But with mediation, $\theta^{\prime}$ can induce $a_{h}$ by sending the high message, contradicting equilibrium.

Whenever an $n$-action equilibrium exists where $n>2$, there exists also a 2 -action equilibrium. Thus Lemma 3 implies that, whenever without mediation there is only a babbling equilibrium, mediation cannot improve upon communication.

\section{A.3 Mediated communication in the case $1 / 2<b<1$}

Here we give the conditions under which the equilibrium described in the full text exists.

The decision maker Given the strategies of the other players and updating of believes by Bayes' rule, the decision maker's actions are optimal by construction.

The mediator First, consider the mediator with bias $b_{M}=\beta$. If he receives message $s_{0}$, and his utility from reporting $m_{1}$ must be greater than his utility from either reporting $m_{0}$ or $m_{23}$ :

$$
\begin{aligned}
& -(p-\beta)^{2} \geq-\beta^{2} \\
& -(p-\beta)^{2} \geq-\left(\frac{6-p}{3-p}-\beta\right)^{2}
\end{aligned}
$$

Solving these inequalities for $\beta$, we have $\beta \geq p / 2$ and

$$
\beta \leq \frac{1}{2}\left(p+\frac{6-p}{3-p}\right) .
$$

If the mediator with bias $\beta$ receives message $m_{1}$, he should prefer sending $m_{23}$ over sending $m_{1}$ :

$$
-\left(\frac{6-p}{3-p}-(1+\beta)\right)^{2} \geq-(p-(1+\beta))^{2}
$$


or equivalently

$$
\beta \geq \frac{1}{2}\left(p+\frac{6-p}{3-p}\right)-1
$$

If inequality (3) holds, then he also has no incentive to send $m_{0}$. Note (3) implies that $\beta \geq p / 2$.

If the mediator with bias $\beta$ receives message $m_{23}$, he should prefer sending $m_{23}$ over sending $m_{1}$ :

$$
-\left(\frac{6-p}{3-p}-\left(\frac{5}{2}+\beta\right)\right)^{2} \geq-\left(p-\left(\frac{5}{2}+\beta\right)\right)^{2}
$$

or

$$
\beta \geq \frac{1}{2}\left(p+\frac{6-p}{3-p}\right)-\frac{5}{2}
$$

which is implied by (3). A fortiori, the mediator has no incentive to send $m_{0}$.

Second, consider the unbiased mediator. After receiving message $s_{0}$, he gets his ideal point by truthful reporting. After receiving message $s_{1}$, he clearly has no incentive to send $m_{0}$, and he also has no incentive to send $m_{23}$ (after all, in this situation, even the biased mediator prefers $m_{1}$ over $m_{23}$ ). If he receives $s_{23}$, he should prefer sending $m_{23}$ over sending $m_{0}$ or $m_{1}$. This is clearly true since

$$
0<p<\frac{6-p}{3-p}<\frac{5}{2}
$$

To summarize, if (2) and (3) hold, the mediator has no incentive to deviate.

The expert Consider type $\theta=0$ of the expert. He has no incentive to send $s_{1}$ whenever

$$
-p b^{2}-(1-p)(p-b)^{2} \geq-p(p-b)^{2}-(1-p)\left(\frac{6-p}{3-p}-b\right)^{2}
$$

or equivalently

$$
b \leq \frac{1}{4} \frac{36-48 p+4 p^{2}+23 p^{3}-13 p^{4}+2 p^{5}}{9-18 p+17 p^{2}-7 p^{3}+p^{4}}
$$

Clearly, deviating $s_{23}$ is worse than deviating to $s_{1}$. 
Consider type $\theta=1$ of the expert. Sending $s_{1}$ is better than sending $s_{0}$. Moreover, he has no incentive to report $s_{23}$ whenever

$$
-(p-(1+b))^{2} \geq-\left(\frac{6-p}{3-p}-(1+b)\right)^{2}
$$

or

$$
b \leq \frac{1}{2}\left(p+\frac{6-p}{3-p}\right)-1 .
$$

From (5) and (3), we have $\beta \geq b$.

Consider type $\theta=2$ of the expert. He has no incentive to send $s_{1}$ (and a fortiori $s_{0}$ ) whenever

$$
-\left(\frac{6-p}{3-p}-(2+b)\right)^{2} \geq-(p-(2+b))^{2}
$$

or

$$
b \geq \frac{1}{2}\left(p+\frac{6-p}{3-p}\right)-2
$$

which is true for any $b>0$.

Similarly, type $\theta=3$ has no incentive to deviate either.

Figure 3 below plots the right hand sides of (4) and (5) as a function of $p$. Assuming $b>0.5$, the inequalities hold in the area under the two curves and above the straight line.

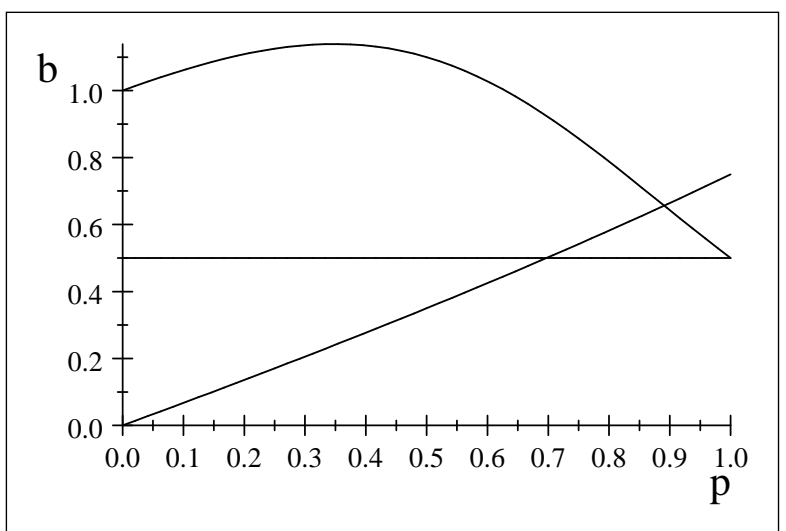

Figure 3: Right hand side of (4) and (5) as a function of $p$. 


\section{A.4 On inequality (1)}

Here we plot the left hand side of inequality (1):

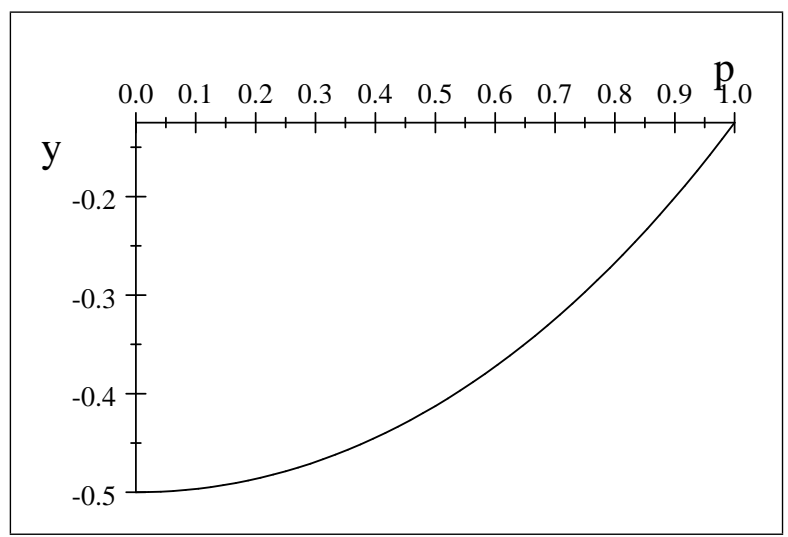

\section{References}

[1] Ambrus, A., E. Azevedo, and Y. Kamada (2010): Hierarchical cheap talk. Working Paper.

[2] Ambrus, A., E. Azevedo, Y. Kamada, and Y. Takagi (2010): Legislative committees as information intermediaries: a unified theory of committee selection and amendment rules. Unpublished manuscript.

[3] Crawford, V.P., and J. Sobel (1982): Strategic Information Transmission. Econometrica, 50, 6, 1431-1452.

[4] Goltsman, M., J. Hoerner, G. Pavlov and F. Squintani (2009): Mediation, arbitration and negotiation. Journal of Economic Theory 144, 4, 13971420 .

[5] Ivanov, M. (2010): Communication via a strategic mediator. Journal of Economic Theory 145, 2, 869-884.

[6] Li, M., and K. Madarasz (2008): When mandatory disclosure hurts: Expert advice and conflicting interests. Journal of Economic Theory 139, 47-74. 
Bücher des Schwerpunkts Märkte und Politik

Books of the Research Area Markets and Politics

Kai A. Konrad, Holger Zschäpitz

Schulden ohne Sühne: Warum der Absturz der Staatsfinanzen uns alle trifft 2010, C. H. Beck

Áron Kiss

Essays in Political Economy and International Public Finance

2009, Peter Lang Verlag

Kai A. Konrad, Tim Lohse (Eds.)

Einnahmen- und Steuerpolitik in Europa:

Herausforderungen und Chancen

2009, Peter Lang Verlag

Kai A. Konrad

Strategy and Dynamics in Contests

2009, Oxford University Press

Roger D. Congleton, Arye L. Hillman, Kai A. Konrad

(Eds.)

40 Years of Research on Rent Seeking

2008, Springer

Kai A. Konrad, Beate Jochimsen (Eds.)

Föderalismuskommission II:

Neuordnung von Autonomie und Verantwortung 2008, Peter Lang Verlag

Mark Gradstein, Kai A. Konrad (Eds.)

Institutions and Norms in Economic Development 2007, MIT Press

Johannes Münster

Mobbers, Robbers, and Warriors

2007, Shaker Verlag

Kai A. Konrad, Beate Jochimsen (Eds.)

Der Föderalstaat nach dem Berlin-Urteil

2007, Peter Lang Verlag

Kai A. Konrad, Beate Jochimsen (Eds.)

Finanzkrise im Bundesstaat

2006, Peter Lang Verlag

Robert Nuscheler

On Competition and Regulation in Health Care

Systems

2005, Peter Lang Verlag

Pablo Beramendi

Decentralization and Income Inequality

2003, Madrid: Juan March Institute

Thomas R. Cusack

A National Challenge at the Local Level: Citizens, Elites and Institutions in Reunified Germany

2003, Ashgate

Sebastian Kessing

Essays on Employment Protection

2003, Freie Universität Berlin

http://www.diss.fu-berlin.de/2003/202
Daniel Krähmer

On Learning and Information in Markets and

Organizations

2003, Shaker Verlag

Tomaso Duso

The Political Economy of the Regulatory Process:

An Empirical Approach

Humboldt-University Dissertation, 2002, Berlin, http://edoc.hu-berlin.de/dissertationen/duso-tomaso2002-07-17/PDF/Duso.pdf

Bob Hancké

Large Firms and Institutional Change. Industrial Renewal and Economic Restructuring in France 2002, Oxford University Press

Andreas Stephan

Essays on the Contribution of Public Infrastructure to Private: Production and its Political Economy

2002, dissertation.de

Peter A. Hall, David Soskice (Eds.)

Varieties of Capitalism

2001, Oxford University Press

Hans Mewis

Essays on Herd Behavior and Strategic Delegation 2001, Shaker Verlag

Andreas Moerke

Organisationslernen über Netzwerke - Die

personellen Verflechtungen von Führungsgremien

japanischer Aktiengesellschaften

2001, Deutscher Universitäts-Verlag

Silke Neubauer

Multimarket Contact and Organizational Design

2001, Deutscher Universitäts-Verlag

Lars-Hendrik Röller, Christian Wey (Eds.)

Die Soziale Marktwirtschaft in der neuen

Weltwirtschaft, WZB Jahrbuch 2001

2001, edition sigma

Michael Tröge

Competition in Credit Markets: A Theoretic

Analysis

2001, Deutscher Universitäts-Verlag

Torben Iversen, Jonas Pontusson, David Soskice

(Eds.)

Unions, Employers, and Central Banks

2000, Cambridge University Press

Tobias Miarka

Financial Intermediation and Deregulation:

A Critical Analysis of Japanese Bank-Firm-

Relationships

2000, Physica-Verlag 
Áron Kiss

Benny Geys Friedrich Heinemann

Alexander Kalb

Salmai Qari

Kai A. Konrad

Benny Geys

Kai A. Konrad

Salmai Qari

Sven Chojnacki

Nils Metternich Johannes Münster

Oliver Gürtler Johannes Münster

Dan Kovenock

Brian Roberson

Subhasish M.

Chowdhury

Dan Kovenock

Roman M. Sheremeta

Michael R. Baye

Dan Kovenock Casper G. de Vries

Florian Morath Johannes Münster

Benny Geys

Paolo Buccirossi

Lorenzo Ciari

Tomaso Duso

Giancarlo Spagnolo

Cristiana Vitale

Pedro P. Barros Joseph Clougherty

Jo Seldeslachts

Paolo Buccirossi

Lorenzo Ciari

Tomaso Duso

Giancarlo Spagnolo

Cristiana Vitale

Paolo Buccirossi

Lorenzo Ciari

Tomaso Duso

Giancarlo Spagnolo

Cristiana Vitale
Coalition Politics and Accountability

SP II $2009-01$

Voter Involvement, Fiscal Autonomy and Public

SP || 2009-02

Sector Efficiency: Evidence from German

Municipalities

Patriotism, Taxation and International Mobility

SP || $2009-03$

The Last Refuge of a Scoundrel? Patriotism and

Tax Compliance

Mercenaries in Civil Wars, 1950-2000

SP II 2009- 05

Sabotage in Dynamic Tournaments

SP || $2009-06$

Non-Partisan 'Get-Out-the-Vote' Efforts and Policy

Outcomes

An Experimental Investigation of Colonel Blotto

Games

SP || $2009-07$

SP || $2009-08$

Contests with Rank-Order Spillovers

SP || $2009-09$

Information Acquisition in Conflicts

SP || $2009-10$

SP || $2009-11$

Wars, Presidents and Popularity:

The Political Cost(s) of War Re-examined

Competition policy and productivity growth:

An empirical assessment

SP II $2009-12$

How to Measure the Deterrence Effects of Merger

SP || $2009-13$

Policy: Frequency or Composition?

Deterrence in Competition Law

SP || $2009-14$

Measuring the deterrence properties of competition

SP II $2009-15$ 
Talat Mahmood The Decision to Migrate: A Simultaneous Decision

SP || $2009-17$ Klaus Schömann Making Approach 
Dorothea Kübler

Dietmar Fehr

Dorothea Kübler

David Danz

Alastair R. Beresford

Dorothea Kübler

Sören Preibusch

Julia Schmid

Dietmar Fehr

Benny Geys

Margarita Kalamova

Kai A. Konrad

Kai A. Konrad

Florian Morath

Wieland Müller

Kai A. Konrad

Benny Geys

Kai A. Konrad

Kai A. Konrad

Kai A. Konrad

Rabah Amir

Natalia Lazzati

Joseph A Clougherty

Tomaso Duso

Kristof De Witte

Benny Geys

Kai A. Konrad

Florian Morath

Tomaso Duso

Klaus Gugler

Florian Szücs

Florian Morath

Changxia Ke

Kai A. Konrad

Florian Morath

Lydia Mechtenberg Johannes Münster
Experimental Practices in Economics:

Performativity and the Creation of Phenomena

Information and Beliefs in a Repeated

Normal-form Game

Unwillingness to Pay for Privacy:

A Field Experiment

Exclusion in the All-Pay Auction: An Experimental Investigation

War Casualties and US Presidential Popularity: A Comparison of the Korean, Vietnam and Iraq War

Nation Brands and Foreign Direct Investment

Taxation and Market Power

SP || $2010-01$

SP || 2010-02

SP II $2010-03$

SP II $2010-04$

SP || $2010-05$

SP || 2010-06

SP || $2010-07$

SP || $2010-08$

Portfolios and Loyal Customers

Federalism and Optimal Allocation Across Levels of Governance

Dynamic Contests

SP || $2010-10$

SP II $2010-11$

Search Costs and Corporate Income Tax

Competition

Network Effects, Market Structure and Industry

Performance

Using Rival Effects to Identify Synergies and Improve Merger Typologies

Evaluating Efficient Public Good Provision:

Theory and Evidence from a Generalised

Conditional Efficiency Model for Public Libraries

Social Mobility and Redistributive Taxation

SP || $2010-15$

SP || $2010-16$

An Empirical Assessment of the 2004 EU Merger Policy Reform

Volunteering and the Strategic Value of Ignorance

SP || $2010-17$

Brothers in Arms - An Experiment on the Alliance Puzzle

SP || $2010-18$

SP II $2010-19$
A strategic mediator who is biased into the same direction as the expert can improve information transmission 


\section{Absender I Return Address:}

Wissenschaftszentrum Berlin

für Sozialforschung

Presse- und Informationsreferat

Reichpietschufer 50

D-10785 Berlin-Tiergarten

Hiermit bestelle ich folgende(s) Discussion paper(s):

Bestell-Nr. I Order no.
Please send me the following Discussion paper(s):

Autor/in, Kurztitel /Author(s) / Title(s) in brief 